\title{
The importance of psychology in the COVID-19 pandemic
}

\author{
Alinne Luzia Timóteo Silva; Anna Paula Correia Barbosa da Silva ${ }^{2 *}$; Bárbara Alice Oliveira da \\ Silva ${ }^{3}$; Bárbara Katyelly Damasceno Silva ${ }^{4}$ Fabrícia Alexandrina Leonel Rodrigues Gomes ${ }^{5}$; \\ Fernanda Laís Gomes Araujo ${ }^{6}$; Geane Camila da Silva ${ }^{7}$; Mykael da Silva Lins ${ }^{8}$; Kamyla Lays da \\ Silva Tavares ${ }^{9}$; Pierre Teodosio Felix ${ }^{10}$
}

1-9 Psychology Students at University Center of Vitória de Santo Antão (UNIVISA), Vitória de Santo Antão, Pernambuco, Brazil

10 Professor of Psychology Course at University Center of Vitória de Santo Antão (UNIVISA), Vitória de Santo Antão, Pernambuco, Brazil

E-mail adresses: alinnetimoteos@gmail.com (Alinne Luzia Timóteo Silva), anna12santana42@gmail.com (Anna Paula Correia Barbosa da Silva), alicebarbara132@gmail.com (Bárbara Alice Oliveira da Silva),barbarakatyelly@gmail.com (Bárbara Katyelly Damasceno Silva), fabriciaalexandrinaleonel@gmail.com (Fabrícia Alexandrina Leonel Rodrigues Gomes), Fernandag78r@gmail.com (Fernanda Laís Gomes Araújo), geanecamila28@gmail.com (Geane Camila da Silva), linsmykael@gmail.com (Mykael da Silva Lins), kamyllalays87@gmail.com (KamylaLays Da Silva Tavares), pierrefelix@univisa.edu.br (Pierre Teodosio Felix)

*Corresponding author

\section{To cite this article:}

Silva, A.L.T.; Silva, A.P.C.B.; Silva, B.A.O.; Silva, B.K.D.; Gomes, F.A.L.R.; Araujo, F.L.G.; Silva, G.C.; Lins, M.S.; Tavares, K.L.S.; Felix, P.T. The importance of psychology in the COVID-19 pandemic. International Journal of Sciences. Vol. 2, No. 3, 2021, pp.121-124. ISSN 2763-5392.

Received: 10 28, 2021; Accepted: 10 30, 2021; Published: 11 03, 2021

\begin{abstract}
The concern for the mental health of the population intensifies during a serious social crisis. The Coronavirus Disease 2019 pandemic (COVID-19) can be described as one of these crises, which has been characterized as one of the biggest international public health problems in recent decades, having hit virtually the entire planet. An event like this causes psychological and social disorders that affect the coping capacity of the whole society, at various levels of intensity and propagation. Recently, different international organizations have expressed their concern about the urgency of mental health care in the COVID-19 pandemic, and it is worth mentioning the Brazilian Ministry of Health, which also emphasized the relevance of this issue in the country.
\end{abstract}

Keywords: Well-being. COVID-19. Pandemic. Mental health.

\section{Introduction}

The new respiratory syndrome caused by the new coronavirus (COVID-19) was initially detected in 2019 in Wuhan, capital of central China province. Reaching people at different levels of complexity, in more severe cases is affected by acute respiratory failure that requires intensive hospital care- including the use of mechanical ventilation. (CDC, 2020). By mid-April 2020, more than two million reported cases and nearly 150,000 deaths worldwide had been counted, with the United States (USA) leading the number of deaths (more than $25,000)$. The ease of propagation, the lack of knowledge about the virus and the exponential increase in the number of contagions caused the World Health Organization (WHO) to raise the disease to pandemic status in March 2020 (WHO, 2020a).
Combating situations such as this had already been a matter of debate in the $\mathrm{WHO}$, which, in 2007, published a document highlighting the need for prior planning by countries to deal with unexpected crises and disasters (WHO, 2007). It should also be said that other studies on crises in public health had also emphasized that mental health care should be as paramount as primary health care (Douglas et al., 2009; Park and Park, 2020; Stevenson et al., 2009).

As for mental health, it is important to say that the sequelae of a pandemic are greater than the number of deaths. The health systems of the countries collapse, health professionals are exhausted by the long hours of work and, in addition, the most effective method of control of the disease, which is social distancing, considerably impacts the mental health of the population (Brooks et al., 2020). In addition to the fear of contracting the disease, COVID-19 has caused a 
2 Silva, A.L.T.; Silva, A.P.C.B.; Silva, B.A.O.; Silva, B.K.D.; Gomes, F.A.L.R.; Araujo, F.L.G.; Silva, G.C.; Lins, M.S.; Tavares, K.L.S.; Felix, P.T. The importance of psychology in the COVID-19 pandemic...

sense of insecurity in all aspects of life, from the collective to the individual perspective, from the daily functioning of society to changes in interpersonal relationships (Lima et al., 2020; Ozili and Arun, 2020).

The rapid change in the usual ways of life can contribute to the triggering of reactions and symptoms of stress, anxiety and depression. Additionally, the fear of being affected by a potentially fatal disease, whose cause and progression are still little known, affects people's psychological well-being. To some extent, when experienced lightly, these reactions can act as protective factors, as they lead to more cautious behaviors with regard to exposure to the risks of contagion. (Barari et al., 2020).

Thus, it is intended in this review, to explore in detail, the evolution of psychology in the pandemic context, where psychosomatic problems were intensely exacerbated, such as depression, anxiety, insecurity, stress, among others. May this work help and develop professionals involved, highlighting psychologists, assisting as a therapeutic basis.

\section{Methodology}

It is a set of approaches, techniques and processes used by science to formulate and solve problems of objective acquisition of knowledge, in a systematic way. For this approach articles were retrieved in several databases such as the Scientific Electronic Library Online (SciELO), British Medical Journal (BMJ), Science Direct, National Library of Medicine (NIH). The integration criteria determined for the selection of articles were: texts available in full, articles in Portuguese and in English from 2007 to 2020; master's dissertations and doctoral theses and articles in the integra that portrayed the advancement of psychology in the pandemic context. The text proposes that the most important thing is to produce a scientific knowledge that, besides being useful, is explicitly guided by an ethical project aimed at solidarity and harmony.

\section{Results and Discussion}

Psychology stands out in this context by bringing together theoretical-conceptual foundations and scientific evidence that can be applied and generalized, contributing to an understanding of psychological aspects during the severe contemporary crisis of the COVID-19 pandemic. Current studies show influences of this situation on people's behavior in everyday life and causing anxiety, fear, depression and panic. (Holmes et al., 2020; Jiao et al., 2020). These major abrupt changes in the way of living everyday life associated with the systemic effects of the pandemic on the body, particularly in the brain and cognition (Holmes et al., 2020), bring the issue of mental health to the top of the concerns. (Holmes et al., 2020). Despite the benefits it brings, due to the containment of the disease, quarantine often implies the experience of unpleasant situations that can have impacts on the mental health of those involved. Some stressors in quarantine are: need for removal of friends and family, uncertainty as to the time of distancing (Brooks et al., 2020).
They identified that the negative effects of this measure include symptoms of posttraumatic stress, confusion, and anger. Concerns about supply shortages and financial losses also cause damage to psychological well-being (Shojaei and Masoumi, 2020).

Health professionals seem vulnerable to the psychosocial effects of the COVID-19 pandemic. Those who act directly in the assistance are in what has been called the front line of the pandemic. As sources of stress and overload, the following conditions are pointed out: nature of the infection itself; insufficient testing; lack of vaccines or effective treatment; severe evolution of some patients; lack of personal protective equipment (PPE) and medical supplies; prolonged workloads; inadequate resting conditions. Accessing the mental health of these professionals and their level of stress perception during the duration of this critical period is essential for the identification of conditions that facilitate the fulfillment of their role and preservation of their health, as well as unfavorable conditions, since little is still known in this sense about COVID-19 (Dong, et al., 2020).

It is understood that the consequences of the mental illness generated by the Coronavirus and the multiple factors that surround it are not restricted only to the current moment, but after the pandemic is extinguished, a period in which many people may still be in mental suffering. This will need to be visualized and understood as it refers to the long-term impacts of the pandemic. However, suffering cannot be neglected, the role of the mental health professional is to receive any verbalization of anguish. Thus, the Coronavirus pandemic may impact individuals in different ways. (Danzmann et al., 2020).

Analyzed together, all these factors refer to the relevance of psychological interventions aligned with emerging needs in the current pandemic context. In recent weeks, studies have been published chronicling successful practices that have been adopted, especially in the Asian continent (Duan \& Zhu, 2020; Jiang et al., 2020; Xiao, 2020; Zhou, 2020), guidelines of associations and psychology councils in different countries, such as Brazil (CFP, 2020.), Spain (CGPE, 2020), the United States (American Psychological Association, 2020), as well as recommendations for mental health care by the World Health Organization (WHO, 2020b).

The context of the pandemic has required changes in the professional practices of Psychology, in terms of evaluation and interventions. Thus, the places of action and research of the psychologist change, with a predominance of online activities (Marasca, et al., 2020); (McCord, et al., 2020). Additionally, on March 31, 2020, Ordinance No. 639 of the Ministry of Health was published, which provides for the strategic action "O Brasil Conta Comigo - Profissionais da Saúde", on the training and registration of health professionals to cope with COVID-19, including psychologists (Ministry of Health, 2020). Therefore, it is clear that psychology professionals are able to assist in the development of healthier ways of dealing with the current crisis in health, collaborating at their different levels of activity, political management, epidemiological evaluation 
and primary care (Wang et al., 2020).

It has also been possible, in this context, for a portion of professionals, to obtain new knowledge both about the area of transit, transportation and mobility itself (e.g., research and trials) and related areas (e.g., epidemiology, statistics and mental health). Several areas of psychology education, mental health, psychotherapy, hospital, emergencies and disasters - emphasized the care of the population, with health workers, with public and social policies on the use of technology and virtual tools and also on the formation in psychology specifically in this pandemic context (Sá-Serafim, et al., 2020); (WHO, 2020).

\section{Conclusions}

The importance of psychology in the COVID-19 pandemic is indeed an important theme to be addressed, because as it was clear in this review it is not a case that only affects the physiological, but also the psychological one. This reiterates the finding that, during a pandemic, a high load of negative experiences and emotions is likely to be experienced, raising the need for constant psychological care since the initial period of the problem (Ho et al., 2020; Li et al., 2020). In Brazil, psychologists have made themselves available to provide assistance and reception to those who have been psychologically affected by the COVID-19 pandemic. In addition, the government has called on health professionals to provide volunteer work (MS, 2020). Therefore, it is clear that psychology professionals are able to assist in the development of healthier ways of dealing with the current crisis in health, collaborating at their different levels of activity, political management, epidemiological evaluation and primary care (Wang et al., 2020).

\section{References}

[1] American Psychological Association. (2020). Pandemics Retrieved from https://www.apa.org/practice/programs/dmhi/researchinformation/pandemics. Disponível em: https://www.apa.org/practice/programs/dmhi/researchinformation/pandemics acessado em 09/10/2021.

[2] Barari, S. et al. Evaluating COVID-19 public health messaging in Italy: self-reported Compliance and growing mental health concerns. medRxiv, Cold Spring Harbor, USA 2020. http://doi.org/10.1101/2020.03.27.20042820.

[3] Brooks, S. K., Webster, R. K., Smith, L. E., Woodland, L., Wessely, S., Greenberg, N., \& Rubin, G. J. (2020). The psychological impact of quarantine and how to reduce it: rapid review of the evidence. The Lancet, 395(102227), 912-920 https://doi.org/10.1016/S01406736(20)30460-8.

[4] Centers for Disease Control and Prevention. (2020). Severe outcomes among patients with Coronavirus Disease 2019 (COVID-19): United States, February 12March 16, 2020. Morbidity and Mortality Weekly Report, 69(12), https://doi.org/10.15585/mmwr.mm6912e2.
[5] Chung JPY, Yeung WS. Staff Mental Health SelfAssessment During the COVID-19 Outbreak. East Asian Arch Psychiatry. 2020;30(1):34.

[6] Chen Q, Liang M, Li Y, Guo J, Fei D, Wang L, et al. Mental health care for medical staff in China during the COVID-19 outbreak. Lancet Psychiatry. 2020;7(4):e15$6 . \quad$ Disponível em: https://www.scielo.br/j/jbpsiq/a/3wN8kZGYJVd3B4tF6 Wectgs/ Acessado em: 14/09/2021.

[7] Conselho Federal de Psicologia. (2020). Tecnologia da Informação e da Comunicação durante a pandemia do COVID-19 Brasília. Disponível em: http://www.in.gov.br/en/web/dou/-/resolucao-n-4-de-26de-marco-de-2020-250189333 acessado em: 09/09/2021.

[8] Conselho Federal de Psicologia. (2020). Tecnologia da Informação e da Comunicação durante a pandemia do COVID19. Disponível em: https://atosoficiais.com.br/cfp/resolucao-do-exercicioprofissional-n-4-2020-dispoe-sobre-regulamentacao-deservicos-psicologicos-prestados-por-meio-detecnologia-da-informacao-e-da-comunicacao-durante-apandemia-do-covid19? origin=instituicao acessado em: $14 / 09 / 2021$.

[9] Conselho Federal de Psicologia. (2020). Ofício-Circular $\mathrm{n}^{\circ}$ 40/2020/GTec/CG-CFP Recuperado de https://site.cfp.org.br/wp-

content/uploads/2020/03/SEI CFP-0214041-

Of\%C3\%ADcio-Circular_pdf. Disponível em: https://site.cfp.org.br/wp-

content/uploads/2020/03/SEI CFP-0214041-

Of\%C3\%ADcio-Circular_pdf acessado em: 24/09/2021.

[10] Consejo General de la Psicología de España. (2020, 3 de octubre). Recursos de ayuda psicológica para afrontar el Covid-19. Disponível em: http://www.infocop.es/view_article.asp?id=8670\&cat=4 4 acessado em: 24/09/2021.

[11] Cullen, W., Gulati., G., \& Kelly, B. D. (2020). Mental health in the Covid-19 pandemic. QJM: An International Journal of Medicine, 113(5), 311-312. https://doi.org/10.1093/qjmed/hcaa110.

[12] Danzmann PS, Silva ACP, Guazina FMN. Atuação do psicólogo na saúde mental da população diante da pandemia. J. nurs. health. 2020;10(n.esp.):e20104015. Disponível em: https://periodicos.ufpel.edu.br/ojs2/index.php/enfermag em/article/view/18945/11556 acessado em: 24/09/2021.

[13] Douglas, P. K., Douglas, D. B., \& Douglas, K. M. (2009). Preparing for pandemic influenza ant its aftermath: mental health issues considered. International Journal of Emergency Mental Health, 11(3), 137-144. Disponível em: http://www.ncbi.nlm.nih.gov/pubmed/20437844 acessado em: 01/10/2021

[14] Duan, L., \& Zhu, G. (2020). Psychological interventions for people affected by the COVID-19 epidemic. The Lancet Psychiatry, 7(4), 300-302. http://dx.doi.org/10.1016/S2215-0366(20)30073-0.

[15] Ho, C., Chee, C., \& Ho, R. (2020). Mental health strategies to combat the psychological impact of COVID-19 beyond paranoia and panic. Annals Academy Medical of Singapure, 49(3), 1-3. R Disponível em: 
4 Silva, A.L.T.; Silva, A.P.C.B.; Silva, B.A.O.; Silva, B.K.D.; Gomes, F.A.L.R.; Araujo, F.L.G.; Silva, G.C.; Lins, M.S.; Tavares, K.L.S.; Felix, P.T. The importance of psychology in the COVID-19 pandemic...

http://www.annals.edu.sg/pdf/special/COM20043 HoC SH 2.pdf acessado em: 09/10/2021.

[16] Holmes et al., 2020 Disponível em: https://www.scielo.br/j/estpsi/a/Q3LCy6Gc6QjPj39Fdc D5hCc/?lang=pt acessado em: 24/09/2021.

[17] Jiang, X., Deng, L., Zhu, Y., Ji, H., Tao, L., Liu, L., ... Ji, W. (2020). Psychological crisis intervention during the outbreak period of new coronavirus pneumonia from experience in Shanghai. Psychiatry Research, 286, 112903.

http://dx.doi.org/10.1016/j.psychres.2020.112903.

[18] Lima, C. K. T., Carvalho, P. M. M., Lima, I. A. S., Nunes, J. A. V. O., Saraiva, J. S., Souza, R. I., ... Rolim Neto, M. L. (2020). The emotional impact of coronavirus 2019Ncov (new Coronavirus Disease). Psychiatry Research, 287 , https://doi.org/10.1016/j.psychres.2020.112915 e112915.

[19] Linhares, M. B. M., \& Enumo, S. R. F. (2020). Reflexões baseadas na Psicologia sobre efeitos da pandemia COVID-19 no desenvolvimento infantil. Estudos de Psicologia (Campinas), 37, e200089 https://doi.org/10.1590/1982-0275202037e200089.

[20] Marasca, A. R., Yates, D. B., Schneider, A. M. A., Feijó, L. P., \& Bandeira, D. R. (2020). Avaliação psicológica on-line: considerações a partir da pandemia do novo coronavírus (Covid-19) para a prática e o ensino no contexto à distância. Estudos de Psicologia (Campinas), 37, e200085. http://doi.org/10.1590/1982$0275202037 \mathrm{e} 200085$.

[21] McCord, C., Bernhard, P., Walsh, M., Rosner, C., \& Console, K. (2020). A consolidated model for telepsychology practice [Ahead of Print] Journal of Clinical https://dx.doi.org/10.1002/jclp.22954.

Psychology.

[22] Ministério da Saúde (Brasil). (2020b). Saúde mental e atenção psicossocial na COVID-19: um guia para gestores Fiocruz: Autor. Disponível em: http:/www.fiocruzbrasilia.fiocruz.br/wpcontent/uploads/2020/04/Sa\%c3\%bade-Mental-eAten $\%$ c 3\%a $\% \%$ c3\%a3o-Psicossocial-na-PandemiaCovid-19-recomenda\%c3\%a7\%c3\%b5es-paragestores.pdf acessado em: 12/09/2021.

[23] Ministério da Saúde. (2020). Portaria no 639, de 31 de março de 2020. Dispõe sobre a Ação Estratégica "O Brasil Conta Comigo - Profissionais da Saúde", voltada à capacitação e ao cadastramento de profissionais da área de saúde, para o enfrentamento à pandemia do coronavírus (COVID-19). Diário Oficial da União Brasília: Disponível em: http://www.in.gov.br/en/web/dou/-/portaria-n-639-de31-de-marco-de-2020-250847738 acessado em: 03/09/2021.

[24] Park, S., \& Park, Y. C. (2020). Mental health care measures in response to the 2019 novel coronavirus outbreak in Korea. Psychiatry Investigation, 17(2), 85-86. ttps://doi.org/10.30773/pi.2020.0058

[25] Sá-Serafim, R., Do Bú, E., \& Lima-Nunes, A. (2020). Manual de diretrizes para atenção psicológica nos hospitais em tempos de combate ao Covid-19. Revista Saúde \& ciência Online, 8(2), 1-24. Disponível em: https://www.researchgate.net/publication/340315850_M anual de Diretrizes para Atencao Psicologica nos $\mathrm{H}$ ospitais_em_Tempos_de_Combate_ao_COVID-19 acessado em: 11/09/2021.

[26] Schmidt B, Crepaldi MA, Bolze, SDA, Neiva-Silva L, Demenech LM. Saúde mental e intervenções psicológicas diante da pandemia do novo coronavírus (COVID-19). Estud. Psicol. (Campinas, Online). [Internet]. Disponível em: https://www.scielo.br/pdf/estpsi/v37/1678-9865-estpsi37-e200063.pdf acessado em: 08/09/2021.

[27] Stevenson, E., Barrios, L., Cordell, R., Deloizier, D., Gorman, S., Koenig, L. J., ... Singleton, C. (2009). Pandemic influenza planning: addressing the needs of children. American Journal of Public Health, 99(2), 255$260 . \quad$ Disponível em: http://ajph.aphapublications.org/doi/pdf/10.2105/AJPH. 2009.159970 acessado em: 08/09/2021.

[28] Wang, C., Pan, R., Wan, X., Tan, Y., Xu, L., Ho, C. S., \& Ho, R. C. (2020). Immediate psychological responses and associated factors during the initial stage of Coronavirus Disease (COVID-19) epidemic among the general population in China. International Journal of Environmental Research and Public Health, 17(5), 1729. http://dx.doi.org/10.3390/ijerph17051729.

[29] Wind, T. R., Rijkeboer, M., Andersson, G., \& Riper, H. (2020). The COVID-19 pandemic: the 'black swan' for mental health care and a turning point for e-health. Internet Interventions, 20, e10317. http://dx.doi.org/10.1016/j.invent.2020.100317.

[30] World Health Organization. (2020). Coronavirus disease 2019 (COVID-19): situation report - 78. Geneva: Author. Disponível em: http://www.who.int/docs/defaultsource/coronaviruse/situation-reports/20200407-sitrep78-covid-19.pdf?sfvrsn=bc43e1b 2 acessado em: $15 / 09 / 2021$.

[31] World Health Organization. (2007). Risk reduction and emergency preparedness: World Health Organization six-year strategy for the health sector and community capacity development Geneva: Author. Disponível em: http://apps.who.int/iris/bitstream/handle/10665/43736/9 $789241595 \quad 896$ eng.pdf?sequence $=1$ \&isAllwed=y acessado em: 10/10/2021.

[32] World Health Organization. (2020). Mental health and psychosocial considerations during the COVID-19 outbreak Geneva. Disponível em: https://www.who.int/docs/defaultsource/coronaviruse/mental-health-considerations.pdf acessado em: 09/09/2021.

[33] Wang et al.,2020. Immediate psychological responses and associated factors during the initial stage of Coronavirus Disease (COVID-19) epidemic among the general population in China. International Journal of Environmental Research and Public Health, 17(5), 1729. http://dx.doi.org/10.3390/ijerph17051729.

[34] Xiao, C. (2020). A novel approach of consultation on 2019 novel coronavirus (COVID-19)-related psychological and mental problems: structured letter therapy. Psychiatry Investigation, 17(2), 175-176. http://dx.doi.org/10.30773/pi.2020.0047.

[35] Zhang, J., Wu, W., Zhao, X., \& Zhang, W. (2020). Recommended psychological crisis ntervention response 
to the 2019 novel coronavirus pneumonia outbreak in China: a model of West China Hospital. Precision $\begin{array}{llr}\text { Clinical } & \text { Medicine, }\end{array}$ https://doi.org/10.1093/pcmedi/pbaa006.

[36] Zhou, X. (2020). Psychological crisis interventions in Sichuan Province during the 2019 novel coronavirus outbreak. Psychiatry Research, 286, 112895. http://dx.doi.org/10.1016/j.psychres.2020.112895. 